diam.; pedicelli penduli, stellato-pilosi, articulati, ad $3 \mathrm{~cm}$. longi; calycis tubus turbinatus, extus stellato-pilosus, dentes triangulares, acuti, extus stellato-pilosi, intus hirtelli; corollae segmenta oblongo-elliptica, obtusa, $12 \mathrm{~mm}$. longa, $6 \mathrm{~mm}$. lata, extus dense stellato-pilosula, intus adpresse stellato- et simpliciter pilosula; stamina 12-14, interdum 10, filamentis inferne dilatatis et complanatis, superne attenuatis, stellato- et simpliciter pilosa, $4 \mathrm{~mm}$. longi, cum connectivo viridi continua; antherae oblongae, luteae, obtusae, dense pilosae, pilis stellatis conspersae, $4 \mathrm{~mm}$. longi; ovarium oblongo-ellipticum, glabrum, $6 \mathrm{~mm}$. longum, 3-4locularae; stylus subulatus, $8 \mathrm{~mm}$. longus, stigmate terminali obscure 3-lobo, lobis minute papillosis; ovula in quoque loculo 2-seriata, 8, erecta, saepius pro parte abortiva. Fructus ligneus, indehiscens, apex late conicus, ceterum obovoideus, cinereo-brunneus, verrucosus, apice acuto $7 \mathrm{~mm}$. longo incluso $1.9 \mathrm{~cm}$. longus, $1.3 \mathrm{~cm}$. diam., exocarpio suberoso, saepius irregulariter transverse fisso $3.5 \mathrm{~mm}$. crasso, endocarpio ligneo $1.5 \mathrm{~mm}$. crasso; semina in quoque fructu solitaria, oblongo-linearia, $1 \mathrm{~cm}$. longa, testa castaneo-brunnea coriacea, albumine carnoso.

KinNGsu: Nanking, in woods, $R$. C. Ching, no. 3458, Sept. 25, 1927, $Y$. L. Keng, no. 1376, April 22, 1928 (type).

The discovery of a new genus in an open country as Nanking, within a few miles of the metropolis, is a rare occurrence. Only one small tree has been located so far. In late April the tree is loaded with showy pendulous white flowers. At first glance it looks more like a rosaceous tree than a Styrax, but when the flowers are examined in detail, its affinity is at once revealed. Its inferior ovary and indehiscent wingless fruit exclude it from such genera as Styrax, Pterostyrax, Halesia or Alniphyllum, and I can only suggest its affinity to Handel-Mazzetti's Melliodendron, from which it differs in several characters. That the exocarp of the old fruit is irregularly transversely fissured is also an interesting character not known in other genera of this family.

\title{
NOTES ON CHINESE BERBERIS
}

J. T. P. BYHOUWER

While identifying the Berberis specimens collected by J. F. Rock in Northern China, and comparing it with the material in the herbarium of Arnold Arboretum, I found among the indetermined material two new species and a new variety. The diagnoses of these Berberis will be found below, followed by a list of those species, of which the geographic distribution has become more completely known since the publication of C. Schneider's Weitere Beiträge zur Kenntnis der chinesischen Arten der Gattung Berberis (in Oesterr. Bot. Zeitschr. LXVL 315-326 [1916], LXvir. 15-32, 135-146, 213-228, 284-300 [1918]) and A. Rehder's Enumeration of the ligneous plants of Northern China, Berberidaceae (in Jour. Arnold Arb. v. 138-144 [1924]). 
Berberis reticulata, spec. nov.

Frutex ad 2-metralis; ramuli annotini et biennes purpurascentes, glabri, angulati, vetustiores cinereo-brunnescentes; internodia 1.5-4 cm. longa; spinae pleraeque simplices, parvae, ad $9 \mathrm{~mm}$. longae. Folia ad 6 fasciculata, spathulato-obovata, tenuia, apice obtusa vel rotundata, mucronulata, basim versus in petiolum $2-12 \mathrm{~mm}$. longum decurrentia, margine anguste aequaliter spinoso-dentata, spinis $1 \mathrm{~mm}$. longis, supra viridia, subtus cinerea, utrinque distincte reticulata, petiolis inclusis $2.0: 0.9-4.0: 1.6-5.6: 2.1 \mathrm{~cm}$. magna. Inflorescentiae breviter corymboso-racemosae, ad 8-florae, 1.4-2.0 cm. longae, glabrae; pedicelli 4-7 $\mathrm{mm}$. longi, basi bracteis acuminatis $1 \mathrm{~mm}$. longis suffulti; flores flavi, extus rubescentes, satis magni (circiter $11 \mathrm{~mm}$. diam.), sepala interna late obovata, $7 \mathrm{~mm}$. longa, petalis obovatis apice emarginatis basi nectariis ovalibus instructis majora; stamina normalia; ovaria ovulis 2 sessilibus instructa. Fructus ovales, rubri, leviter pruinosi, ad 11 : $8 \mathrm{~mm}$. magni, stigmatibus sessilibus coronati.

Northern China: without precise locality, Wm. Purdom, no. 644 (seeds only); plants raised from this seed cultivated in the Arnold Arboretum under no. 20081. Specimens examined: A. Rehder May 11 and 21, 1927 (type), May 15, 1918, May 16, 1919, May 15, 1922, Sept. 14, 1922, L. V. Schmitt, Sept. 23, 1926.

This species seems to be related to Berberis Silva-Taroucana Schneider and $B$. Mouillacana Schneider of the section Tschonoskyanae, and Berberis Boschanii Schneider and B. Lecomtei Schneider of the section Sinenses. The leaf-texture and the rather big fruits resemble those of species of the former, the short inflorescence, the small spines and the red-tinged flowers suggest the latter section, in which it could best be placed. It differs from all species mentioned in the corymbose inflorescense, the larger flowers and the strongly reticulate leaf.

\section{Berberis Cavaleriei var. pruinosa, var. nov.}

Berberis sp. Rehder in Jour. Arnold Arb. vir. 108 (1927).

A typo recedit foliis subtus albescentibus, pruinosis.-Ramuli flavi, angulati; spinae trifidae, flavescentes, mediae ad $2.5 \mathrm{~cm}$. longae. Folis tenuiter coriacea, oblonga, $3: 1$ ad $5: 1.4 \mathrm{~cm}$. magna, apice acuta, basi cuneata in petiolum ad $3 \mathrm{~mm}$. longum attenuata, margine distanter spinuloso-serrata (dentibus $0.5-1 \mathrm{~mm}$. longis $1-3$ pro $1 \mathrm{~cm}$.), superne viridia, subnitentia, supra albopruinosa, utrinque laxe nervata. Inflorescentiae fasciculatae, 6-12-florae. Fructus pruinosi, stylo brevi excluso $7 \mathrm{~mm}$. longi et $4 \mathrm{~mm}$. crassi, semina 2; pedicelli 14-18 mm. longi.

SOUTHERN ANHwEI: Chang gon shan, Wu yuan, thickets in ravine, R. C. Ching, no. 3248 (type), Aug. 17, 1925 (shrub $1 \mathrm{~m}$. tall, leaves evergreen, dull shining green, fruit greenish, pendulous). This variety seems to be the extreme eastern form of the widely distrib-
uted species. 
Berberis densifolia, spec. nov.

Frutex 0.3-1.2 m. altus; ramuli juniores geniculati, sulcato-angulati, flavi, vetustiores flavescenti-cinerascentes; internodia $1-2(-4) \mathrm{cm}$. longa; spinae tripartitae, flavae, mediae ad $1.3 \mathrm{~cm}$. longae. Folia ad 6 fasciculata, crasse coriacea, cuneata vel oblanceolata, apice sensim acuta, mucronata, basi sensim in petiolum 1-2 mm. longum attenuata, margine saepe revoluta, versus apicem dentibus 1-3 munita, minora $1 \mathrm{~cm}$. longa, 5-6 mm. lata, majora $3 \mathrm{~cm}$. longa, 7-10 mm. lata, supra viridia, subtus albo-pruinosa vel in sicco ferruginea, indistincte laxe reticulata. Flores nondum vidi. Fructus ad 3 fasciculati, ovales, circiter 7-9:6 mm. magni, stylo brevi coronati, atrocoerulei; pedicelli ad $7 \mathrm{~mm}$. longi; semina 3.

Formosa: Prov. N a n t o: Mount Kiraishui, alt. $3500-8600 \mathrm{~m}$., E. H. Wilson, no. 10074 (type), Mar. 6, 1918 (bush 0.3-1.2 m., fruit blue-black).

The nearest relatives among the Chinese species appear to be Berberis triacanthophora Fedde, which has, however, reddish-brown, round twigs and much longer flower-stalks and B. replicata W. W. Smith, which differs in having round twigs, longer flower-stalks and smaller fruits.

The other Formosan species can all be easily distinguished: Berberis aristato-serrulata Hayata by the finely serrulated leaf-margin, Berberis Kawakamii Hayata by the larger, more strongly reticulate and nonpruinose leaves and the 10-15-flowered inflorescenses with longer pedicels, Berberis brevisepala Hayata by the uniovulate ovaries, the red twigs and the larger and wider leaves, Berberis mingetsensis Hayata by the very large, strongly reticulate leaves.

Berberis densifolia Wilson no. 10074 has been distributed as Berberis Kawakamii Hayata.

Berberis Cavaleriei Léveillé in Fedde Rep. Spec. Nov. Ix. 454 (1911).Schneider in Oesterr. Bot. Zeitschr. LXvII. 140 (1918).

Berberis Griffithiana Léveillé Fl. Kouy-Tcheou. 48 (1914). - Non Schneider.

The type-specimens were collected in Kweichow by $J$. Cavalerie (no. 3209), it has now been found also in Chekiang (R. C. Ching, Plants of Chekiang, no. 2336), Hunan (Handel-Mazetti, no. 438, inter urbes Linling and Sinning, alt. $200-500 \mathrm{~m}$. and no. 552, ad minas Hsikwangschan prope urbem Hsinhwa, in fruticetis, alt. 600-800 m.) and the variety pruinosa Byhouwer in Anhwei (R. C. Ching, no. 3248).

Berberis Kawakamii Hayata in Jour. Coll. Sci. Tokyo xxx. Art. I. 24 (1911); Icon. Pl. Formos. I. 40, t. 9 (1911); l. c. II. 4 (1914).-Kanehira, Formos. Trees 32, fig. (1917).- Schneider in Oesterr. Bot. Zeitschr. LXVII. 140 (1918).

The original material was found by T. Kawakami on Mt. Morrison, alt. $2700 \mathrm{~m}$.; among E. H. Wilson's specimens three are from the same province (no. 9720, Arisan, prov. Kagi, alt. $2333-2933$ m., no. 10910, Arisan to Mt. Morrison, prov. Kagi, alt. 2666-3666 m., and no. 10952, 
Arisan to Mt. Morrison, alt. $3666 \mathrm{~m}$.), and one from province Nanto (no. 10060, from Nanto to Noko via Musha, alt. 2666-3166 m.).

Berberis silvicola Schneider in Sargent Pl. Wils. III. 438 (1917).

The type-material was found by E. H. Wilson in western Hupeh (no. 2879); it appears to grow also in Yunnan (G. Forrest, no. 18195), so probably it is still to be found in Szechuan or Kweichow.

Berberis diaphana Maximowicz in Bull. Acad. Sci. St. Pétersb. xxiI. 309 (1876); in Mél. Biol. IX. 712 (1877); Fl. Tangut. 32, t. 8, fig. 1-7 (1889); in Act. Hort. Petrop. XI. 42 (1890).-Hemsley in Jour. Linn. Soc. xxIIr. 31 (1886).-Schneider in Bull. Herb. Boiss. sér. 2, v. 398 (1905); vIII. 195 (1908); in Oesterr. Bot. Zeitschr. LXvI. 321 (1916).Fedde in Bot. Jahrb. xxxvı. beibl. LxxxII. 44 (1905).- Rehder in Sargent, Trees \& Shrubs, II. 19, t. 109 (1907); in Jour. Arnold Arb. v. 139 (1924).

Berberis yunnanensis Hutchinson in Bot. Mag. cxxxiv. t. 8284 (1908).Non Franchet.

Discovered in Kansu by N. Przewalski, this species has been collected in the same province by $G$. N. Potanin, R. C. Ching (Wulsin Expedition no. 432, 556, 961) and J. F. Rock (no. 12634, 13474, 13525, 13529, 13574). In Shensi it was found by $G$. Giraldi (Fedde l.c.), in Szechuan by Farges (Eastern Szechuan, Tchen-keou-tin, 1893) and E. H. Wilson (Western Szechuan, no. 930, 4190, 2865, 4170). Recent material shows that the range of the species extends further south-west and west; it has been found by Handel-Mazetti in northwestern Yunnan (no. 8117, ad confines tibeticas sub jugo Dokerla, $28^{\circ} 15^{\prime}$, in regionis frigide temperatae abieto-salicetis, alt. $3800-4150 \mathrm{~m}$.) and by J. F. Rock in eastern Tibet (no. 13263, 13272, 13273, 14100, 14108, 14115).

Berberis aemulans Schneider in Sargent, Pl. Wils. III. 434 (1917); in Oesterr. Bot. Zeitschr. Lxvr. 321 (1916).

Berberis diaphana Schneider in Sargent, Pl. Wils. I. 353 (1913), ex parte.Non Maximowicz.

The type-locality for this species is western Szechuan, Wa-shan (E. H. Wilson, no. 930), other material collected by E. H. Wilson comes from the same province (no. 3145,4190 , Sungpan). It appears to grow also in northwestern Yunnan, as shown by the following specimens of G. Forrest; no. 19521, margins of pine forests on the Mekong-Salwin divide, lat. $27^{\circ} 54^{\prime}$, long. $98^{\circ} 50^{\prime}$, alt. $3000-3300 \mathrm{~m}$. and no. 20295 , Mekong-Salwin divide, Sie-la, lat. $28^{\circ}$, long. $98^{\circ} 40^{\prime}$, alt. $4000-4300 \mathrm{~m}$.

Berberis Faxoniana Schneider in Oesterr. Bot. Zeitschr. LXvI. 325 (1916).

About the geographic distribution of this species nothing was known, as Schneider described it from material grown in Arnold Arboretum and perhaps introduced from Vilmorin's nurseries. The numbers 13829 , 16554 and 18992 of the Plantae Forrestianae from Yunnan appear to be 
Berberis Faxoniana, but the labels do not give any clue in which part of Yunnan this material has been collected.

Berberis Wilsonae var. subcaulialata Schneider in Oesterr. Bot. Zeitschr. LXVII. 298 (1918).

Berberis subcaulialata Schneider in Fedde Rep. Spec. Nov. vi. 267 (1909); in Sargent, Pl. Wils. I. 369 (1913).-Hesse in Mitt. Deutsch. Dendr. Ges. xxII. 266 (1914).-Bean in Gard. Lxxxv. 501, fig. (1921).

Berberis Coryi Veitch, New Hardy Pl. W. China, 7 (1913).

This variety was first collected by E. H. Wilson in western Szechuan (no. 1267), but it is found also in western Yunnan, as shown by the specimens of $\boldsymbol{E}$. $\boldsymbol{E}$. Maire (no. 67, coteaux arides, rocailleux derrière Tong-tchouan, alt. $2990 \mathrm{~m}$., no. 179, collines arides, rocailleuses de Pokio, alt. $2990 \mathrm{~m}$.) and G. Forrest (no. 18516, Yunnan, no. 20179, side valleys on the mountains N. E. of Atuntze, lat. $28^{\circ} 35^{\prime}$ N., long. $99^{\circ} 10^{\prime}$ E., alt. 3300-3600 m., N. W. Yunnan, and no. 20378, ravines on the Mekong-Yangtze divide, lat. $27^{\circ} 36^{\prime} \mathrm{N}$., long. $99^{\circ} 10^{\prime}$ E., alt. $3600 \mathrm{~m}$., N. W. Yunnan.

Berberis aggregata var. Prattii Schneider in Sargent, Pl. Wils. III. 443 (1917); in Oesterr. Bot. Zeitschr. LXvII. 296 (1918).

Berberis polyantha Hemsley in Jour. Linn. Soc. Bot. xxix. 302 (1892), quoad specim. Prattii no. 80.

Berberis Prattii Sehneider in Sargent, Pl. Wils. I. 376 (1913). - Sprague in Bot. Mag. cxi. t. 8549 (1914).

Berberis integerrima Hort. Veitch, pro parte, ex Schneider 1. c. (1918), pro synon.-Non Bunge.

Berberis Geraldii Veitch, New Hardy Pl. W. China 7 (1913), nomen.

Berberis brevipaniculata Bean, Trees and Shrubs I. 236 (1914).-Non Schneider.

The range of this species appears to extend from western Szechuan, where it was discovered (E. H. Wilson, no. 1261 type, $1050 \mathrm{~A}, 1073$, $1300,4173)$ into northwestern Yunnan (G. Forrest, no. 20292, on Dokerla, Mekong-Salwin divide, lat. $28^{\circ} 20^{\prime}$ N., long. $98^{\circ} 40^{\prime}$ E., alt. 3600 m.).

Berberis Caroli Schneider in Bull. Herb. Boiss. sér. 2. v. 459 (1905).

Berberis integerrima var. stenophylla Maximowicz, Fl. Tangut. 29 (1889). Non Berberis stenophylla Lindley, nec Hance.

Berberis integerrima Maximowicz Enum. Pl. Mongol. 33 (1889), quoad specim. ex Ordos.

As mentioned in the enumeration of the Berberis of the Rock collection, two specimens, no. 13314 from northwestern Kansu and no. 14362 from eastern Tibet seem to belong to Berberis Caroli rather than to the closely related Berberis Vernae Schneider. This means a much wider range for $B$. Caroli which was discovered by $G$. N. Potanin in Ordos (southern Mongolia, 1884), and since then no typical material has been found.

Berberis Silva-Taroucana Schneider in Sargent, Pl. Wils. I. 370 (1913); in Oesterr. Bot. Zeitschr. LXvII. 217 (1918).-Hesse in Mitt. Deutsch. Dendr. Ges. XxII. 266 (1914).

The type-speeimen of this species is E. H. Wilson's no. 2860, from 
Chiu ting shan, western Szechuan; other material from the same province constitutes the nos.: $955,1012,1012 \mathrm{~A}, 1059$, 2857, 2858, 2861, $2863 \AA, 2867,3151 \wedge, 4153,4288,4726$. The area in which the species occurs appears to be much larger, as shown by Wilson's no. 645, collected in western Hupeh, and J. F. Rock's nos. 12473, 13522 and 14913 from southwestern Kansu.

Berberis Mouillacana Schneider in Sargent, Pl. Wils. I. 371 (1913); in Oesterr. Bot. Zeitschr. LXviI. 217 (1918).

Berberis Mouillacana was known only from western Szechuan, in the specimens: $E$. $H$. Wilson no. 1039 (type), 1041, 1283, 4123. The specimens collected by $J$. F. Rock demonstrate its occurence in southwestern Kansu, north of the original area (J. F. Rock, nos. 12303, ?12429, 12443, ?12458, 13202, 14898).

Berberis Boschanii Schneider in Sargent, Pl. Wils. I. 369 (1913); in Oesterr. Bot. Zeitschr. LXvIr. 225 (1918).

This is another case of a Berberis, discovered in western Szechuan (E. H. Wilson, no. 1166, type, 3156), which appears to extend northward into Kansu (R. C. Ching, Wulsin Expedition, no. 86 and 773, southwestern Kansu; J. F. Rock, no. 12513, southwestern Kansu and no. 13300 and 13316, northwestern Kansu) and into eastern Tibet (J. F. Rock, no. 13261, 13274, 13366, 13920, 13948, 14073, 14079).

Berberis Lecomtei Schneider in Sargent, Pl. Wils. I. 373 (1913); in Oesterr. Bot. Zeitschr. LXvir. 225 (1918).

i Berberis heteropoda Franchet in Bull. Soc. Bot. France, xxxmr. 386 (1896).Non Schrenck.

Berberis sinensis var. typica Franchet, Pl. Delav. 35 (1889). - Non Poiret.

Berberis Thunbergii var. glabra Franchet, 1. c. 35 (1889). - Schneider in Bull. Herb. Boiss. sér. 2. viI. 204 (1908).

Berberis pallens Diels in Not. Bot. Gard. Edinb. vII. 342 (1912).-Non Franchet.

This species was known to occur in Yunnan, the type-material was collected in that province by Delavay (no. 1047), later more specimens were found by Delavay (no. 2247 and specimens from Kou toui and Lichiang range) and by G. Forrest (nos. 17143, 20621, 20802, 2271 and 2343). Schneider described two specimens from southern Szechuan (nos. 1503 and 1536), found by himself in 1914, as probably belonging to $B$. Lecomtei. A confirmation of the occurrence in this province is given by no. 22395 of $G$. Forrest: side valleys of the mountains southeast of $\mathrm{Mu}$-li, lat. $27^{\circ} 50^{\prime} \mathrm{N}$., long. $101^{\circ} \mathrm{E}$., alt. $3300-3600 \mathrm{~m}$., southwestern Szechuan.

Berberis dasystachya Maximowicz in Bull. Acad. Sci. St. Pétersb. xxIIr. 308 (1877); in Mél. Biol. Ix. 711 (1877); Fl. Tangut. 30, t. 5, fig. 1-7 (1889); in Act. Hort. Petrop. xI. 41 (1890). - Hemsley in Jour. Linn. Soc. xxII. 3 (1886). -Kanitz in Szechenyi, Keletazs. Utján. Tudom. Ered. II. 794 (PI. Enum. 5) (1891); in Szechenyi, Wiss. Ergebn. 
Reise Ostas. II. 681 (1898).-Bretschneider, Hist. Eur. Bot. Disc. China, 971 (1898).-Schneider in Bull. Herb. Boiss. sér. 2, v. 664 (1905); virI. 262 (1908); in Sargent, Pl. Wilson III. 442 (1917); in Oesterr. Bot. Zeitschr. LXvIr. 287 (1918).-Fedde in Bot. Jahrb. xxxvI. beibl. LxxxII. 43 (1905).--Rehder in Jour. Arnold Arb. v. 142 (1924).

Berberis heteropoda var. oblonga Maximowicz in Act. Hort. Petrop. xI. 41 (1890).-Non Regel.

? Berberis dolichobotrys Fedde in Bot. Jahrb. xxxvr. beibl. LxxxIr. 41 (1905).

Berberis vulgaris var. dasystachya Voss in Putlitz \& Meyer, Landlexicon v. 709 (1913).

Originally described from material collected by N. Przewalski in Kansu, the species was found in that province by all subsequent collectors: G. N. Potanin (see Schneider, 1. c. 1905), L. Loczy (see Kanitz, l. c.), W. Purdom (no. 1014), and J. F. Rock (no. 12207, 12465, 12504, $12808,12885,13291,13514,13561,14680)$. Meanwhile it had been discovered in several adjacent provinces: in Hupeh by $A$. Henry (no. 6816), E. H. Wilson (no. 307), and W. Y. Chun (no. 3910, 4219), in Szechuan by Von Rosthorn (no. 962), Farges (see Schneider, 1. c. 1918) and $E$. H. Wilson (no. 4203), in Shensi by G. Giraldi (no. 51, see Fedde l. c.). So it was to be expected also in eastern Tibet, especially in the Kokonor region, between western Szechuan and northwestern Kansu, where it has now been found by $J$. F. Rock (no. 13262).

\section{TWO NEW GENERA AND NEW COMBINATIONS OF RUTACEAE-AURANTIEAE FROM PAPUA}

\section{(REVISIO AURANTIACEARUM II)}

\section{Echinocitrus, ${ }^{1}$ gen. nov.}

\section{Trôzaburô TANaka}

Flores mediocres, axillares, solitarii; calyx cupulatus, basi attenuatus, punctatus, lobis 5 ovato-deltoideis glabris; petala 5 , imbricata, oblongoobovata, basi plus minusve attenuata, punctata; stamina 10 , filamentis filiformibus liberis, antheris linearibus obtusis; ovarium lageniforme, stipitatum, glabrum, apice in stylum attenuatum, stylo staminibus paulo longiore. Bacca obovoidea, frequenter basi elongata, punctata, laevissima, corticosa, 5-locularis; pulpa vesiculari nulla, succo exiguo; semina biseriata, reniformia, compressa.-Frutex ramosissimus, ramis patentibus saepissime pendulis, spinosissimis, spinis geminatis, puberulis. Folia alterna, ovato-rhomboidea, obsolete punctata, nervis utrinque vix prominulis, breviter petiolata.

Genus Triphasiae affine, floribus pentameris longe pedicellatis, foliis simplicibus irregulariter crenulatis, fructibus obovoideis magnitudine cerasi.

Species unica, Paramignya Brassii C. T. White.

${ }^{1}$ From the Greek, ' $\chi$ tvos, hedgehog, and Citrus. 


\section{$2 \mathrm{BHL}$ Biodiversity Heritage Library}

Bijhouwer, J. T. P. 1928. "Notes on Chinese Berberis." Journal of the Arnold Arboretum 9(2-3), 131-137. https://doi.org/10.5962/p.185195.

View This Item Online: https://www.biodiversitylibrary.org/item/33587

DOI: https://doi.org/10.5962/p.185195

Permalink: https://www.biodiversitylibrary.org/partpdf/185195

\section{Holding Institution}

Missouri Botanical Garden, Peter H. Raven Library

\section{Sponsored by}

Missouri Botanical Garden

\section{Copyright \& Reuse}

Copyright Status: In copyright. Digitized with the permission of the rights holder.

Rights Holder: Arnold Arboretum of Harvard University

License: http://creativecommons.org/licenses/by-nc-sa/3.0/

Rights: https://biodiversitylibrary.org/permissions

This document was created from content at the Biodiversity Heritage Library, the world's largest open access digital library for biodiversity literature and archives. Visit BHL at https://www.biodiversitylibrary.org. 